\title{
Melatonin Does Not Affect Progesterone Basal Secretion but Suppresses the Luteinizing Hormone Receptor Expression in Granulosa Cells of the Japanese Quail
}

\author{
Guang-Min $\mathrm{Yu}^{1}$, Naoki Isobe $\mathrm{e}^{1,2}$ and Teruo Maeda ${ }^{1,2}$ \\ ${ }^{1}$ Department of Bioresource Science, Graduate School of Biosphere Science, \\ Hiroshima University, Higashi-Hiroshima 739-8528, Japan \\ ${ }^{2}$ The Research Center for Animal Science, Hiroshima University, Higashi-Hiroshima 739-8528, Japan
}

\begin{abstract}
The aim of this study was to evaluate the potential effect of melatonin on progesterone production by granulosa cells of the Japanese quail. For in vitro experiments, granulosa cells were isolated from pre-ovulatory follicles (F1-F3) when the F1 follicles were predicted to be either immature or mature (at 3-6 or 18-21 h after oviposition, respectively). Granulosa cells were cultured for $12 \mathrm{~h}$ with or without melatonin concentration gradients of 0.0001$100 \mu \mathrm{g} / \mathrm{mL}$, thereby averting luteinizing hormone (LH) stimulation. The concentration of progesterone in culture medium was measured using an enzyme immunoassay. The expression of melatonin receptor subtypes in granulosa cells from F1 follicles was detected by reverse transcription-PCR. The LH receptor (LHCGR) mRNA level in cultured granulosa cells of the F1 follicles was analyzed using quantitative real-time PCR. Six quails were used in each of four groups for in vivo experiments. Each group received intraperitoneal injection of melatonin $(0.67 \mathrm{mg} / \mathrm{kg}$ body weight) or mock-vehicle at 3 or $18 \mathrm{~h}$ after oviposition, respectively. The birds were decapitated to collect serum $3 \mathrm{~h}$ later (at 6 or $21 \mathrm{~h}$ after oviposition, respectively). The serum progesterone level was also measured using an enzyme immunoassay. We observed that melatonin receptor subtypes (Mel-1a, 1b, and 1c) were expressed in the granulosa cells of the F1 follicles of the Japanese quail. Melatonin suppresses the LHCGR mRNA expression in granulosa cells of $\mathrm{F} 1$ follicles but does not affect the basal secretion of progesterone in cultured granulosa cells of the $\mathrm{F} 1-\mathrm{F} 3$ follicles. In addition, melatonin treatment has no influence on the serum progesterone concentration at $6 \mathrm{~h}$ post-oviposition, but suppresses progesterone level $21 \mathrm{~h}$ after oviposition in the Japanese quail.
\end{abstract}

Key words: granulosa cell, Japanese quail, luteinizing hormone receptor, melatonin, progesterone

J. Poult. Sci., 54: 312-318, 2017

\section{Introduction}

Melatonin (N-acetyl-5-methoxytryptamine), a major pineal secretary product, has been regarded as a neurohormone for a long time (Davis, 1997; Pang et al., 1998; Vanecek, 1998). This generally accepted view has recently been challenged by the discovery that melatonin is involved in various physiological processes, such as female reproduction (Wang et al., 2014), innate immunity (Zhou et al., 2016), neuroprotection (Tyagi et al., 2010), abiotic stress resistance (Zhang et al., 2015), and anti-inflammation (Hardeland et al., 2015), antiradiation (Fernández-Gil et al., 2017), anticancer (Moreira et al., 2015; Söderquist et al., 2016), and antioxidant proc-

Received: April 10, 2017, Accepted: May 8, 2017

Released Online Advance Publication: June 25, 2017

Correspondence: Teruo Maeda, Graduate School of Biosphere Science, Hiroshima University, Higashi-Hiroshima 739-8528, Japan.

(E-mail: temaeda@hiroshima-u.ac.jp) esses (Mehaisen et al., 2015), in both plants and animals. Besides melatonin, its metabolites, including cyclic-3-hydroxymelatonin, $\mathrm{N}$-acetyl-N-formyl-5-methoxykynuramine, and $\mathrm{N}$-acetyl-5-methoxykynuramine, also have the ability to scavenge reactive oxygen species and reactive nitrogen species (Galano et al., 2013; Galano et al., 2014). These findings indicate that melatonin is a more universal molecule than previously thought, with functions in various tissues and organs. In mammals, melatonin acts on the ovaries, with direct effects on granulosa cell steroidogenesis and follicular functions (Wang et al., 2012). Melatonin directly stimulates progesterone production by human and bovine granulosa cells in vitro (Webley and Luck, 1986). Perfusion with melatonin markedly stimulated progesterone secretion by the marmoset corpus luteum (Webley and Hearn, 1987). Melatonin also improves the concentration of plasma progesterone in sheep and rats (Abecia et al., 2002; Chuffa et al., 2013). However, there are some notable differences between birds 
and mammals with regard to ovarian function and divergent characteristics of the biosynthesis and role for progesterone. Poultry birds maintain a strict follicular hierarchy consisting of approximately 2 to 6 pre-ovulatory follicles, and ovulate a single follicle almost every day (McDerment et al., 2012). In nearly all species of birds, the synthesis of progesterone within the follicular granulosa is a requirement for ovulation, comparable to the site of synthesis and role of estradiol in mammals (Johnson, 2014). Murayama et al. (1997) indicated the direct action of melatonin on hen ovarian granulosa cells to lower their responsiveness to luteinizing hormone (LH) in vitro. However, reports on the effects of melatonin on progesterone production under basal conditions and the expression of the $\mathrm{LH}$ receptor (LHCGR) in birds are not available.

To fill this gap in our knowledge, we conducted a series of experiments to determine whether melatonin affects progesterone production by the follicular granulosa in Japanese quail. We investigated the effect of melatonin on progesterone production by granulosa cells in vitro at a wide range of concentrations in F1-F3 follicles without $\mathrm{LH}$ stimulation. We also examined the expression of melatonin receptor subtypes and the level of LHCGR mRNA in cultured granulosa cells from F1 follicles stimulated by melatonin. Finally, we investigated the effect of melatonin on progesterone production in vivo.

\section{Materials and Methods}

\section{Experimental Birds}

In total, 36 female Japanese quails, 15-30 weeks of age, were used. All quails were reared in individual cages under a lighting regimen of $14 \mathrm{~h}$ light: $10 \mathrm{~h}$ dark and were provided with feed and water ad libitum. For the in vitro experiment, birds were decapitated to collect pre-ovulatory follicles when the F1 follicles were predicted to be immature or mature, 3-6 or 18-21 h after oviposition, respectively (Reece, 2004). F1-F3 follicles were collected at the same time. For the in vivo experiment, animals were intraperitoneally injected with melatonin $(0.67 \mathrm{mg} / \mathrm{kg}$ body weight; a concentration similar to that used for rat injection [Abd-Allah et al., 2003; Chuffa et al., 2013]) or vehicle at 3 and $18 \mathrm{~h}$ after oviposition. The serum level of melatonin after administration was estimated as $8.38 \mu \mathrm{g} / \mathrm{mL}$, based on the method of Ito et al. (2011). The birds were decapitated to collect serum $3 \mathrm{~h}$ later (at 6 and $21 \mathrm{~h}$ after oviposition). All animals used in this study were handled in accordance with the regulations of the Animal Experiment Committee of Hiroshima University for animal experiments.

\section{Cell Culture and Treatment}

Granulosa cells were isolated as previously described (Rangel et al., 2009). In brief, pre-ovulatory F1-F3 follicles were placed in cell-culture dishes containing preheated Dulbecco's phosphate-buffered saline (DPBS; Nissui Pharmaceutical, Tokyo, Japan). After the yolk was drained out through an incision made in the follicular wall, the follicle was inverted and shaken in sterile DPBS. The granulosa layers detached from the hierarchical follicles were disaggre- gated at $37^{\circ} \mathrm{C}$ for $5 \mathrm{~min}$ under continuous agitation in 500 , 300 , and $200 \mu \mathrm{L}$ of dissociation solution (CTK; ReproCELL, Yokohama, Japan). The enzymatic reaction was quenched by the addition of $2 \mathrm{~mL}$ of Dulbecco's modified Eagle's medium (DMEM)/F12 medium (Gibco BRL/Invitrogen, Karlsruhe, Germany) containing $10 \%(\mathrm{v} / \mathrm{v})$ fetal bovine serum (FBS; Sigma-Aldrich, St. Louis, MO, USA). Cells pellets were flushed with a pipette, and centrifuged. Cells were washed three times by resuspension in $5 \mathrm{~mL}$ DPBS and centrifuged for $5 \mathrm{~min}$ at $500 \times \mathrm{g}$. Granulosa cells were seeded at a concentration of $2 \times 10^{5}$ cells $/ \mathrm{mL}$ in DMEM/F12 medium containing $10 \%(\mathrm{v} / \mathrm{v})$ FBS, $1 \%(\mathrm{v} / \mathrm{v})$ nucleosides (Millipore, Billerica, MA, USA), 1\% (v/v) non-essential amino acids (Gibco BRL/Invitrogen), $1 \mathrm{mM}$ sodium pyruvate (Gibco BRL/Invitrogen), and 1\% (v/v) antibiotic-antimycotic mixed stock solution (Nacalai Tesque, Kyoto, Japan). Cells were cultured at $39^{\circ} \mathrm{C}$ in a humidified atmosphere with $5 \% \mathrm{CO}_{2}$ and $95 \%$ air.

A stock solution of melatonin was prepared by dissolving $10 \mathrm{mg}$ of melatonin (Sigma-Aldrich) in $200 \mu \mathrm{L}$ of ethanol. Working solutions were prepared by dilution in cell culture medium to give a concentration gradient of $0.0001-100$ $\mu \mathrm{g} / \mathrm{mL}$. Granulosa cells were treated with different concentrations of melatonin for $12 \mathrm{~h}$, a culture time used previously (Taketani et al., 2011). As controls, cells were incubated with ethanol at the highest concentration used for melatonin treatment.

\section{RNA Extraction}

At least $5 \times 10^{5}$ cultured granulosa cells from $\mathrm{F} 1$ follicles were used for total RNA extraction. The cell culture medium was aspirated. Adherent cells were washed once with $2 \mathrm{~mL}$ ice-cold DPBS, which was then aspirated as much as possible. The cells were used for total RNA extraction with the NucleoSpin RNA kit (Macherey-Nagel, Düren, Germany), according to the manufacturer's instruction. The obtained RNA pellet was treated with DNase I (Macherey-Nagel) and dissolved in diethyl pyrocarbonate-treated water (Nacalai Tesque). The total RNA was quantified by measuring the optical density at a wavelength of $260 \mathrm{~nm}$ using an $\mathrm{OD}_{260}$ unit equivalent to $40 \mu \mathrm{g} / \mathrm{mL}$ of RNA. The RNA purity was determined by measuring the ratio of absorbance at 260 and $280 \mathrm{~nm}$. Only samples with a ratio between 1.8 and 2.2 were used.

\section{Reverse Transcription (RT)-PCR}

The RNA solution was incubated at $65^{\circ} \mathrm{C}$ for $5 \mathrm{~min}$ and kept on ice afterwards. The total RNA was reverse-transcribed using ReverTra Ace (Toyobo Co. Ltd., Osaka, Japan) to obtain the cDNA. The reaction mixture consisted of 240 ng of total RNA, $5 \times$ reverse transcription buffer, $0.5 \mu \mathrm{L}$ reverse transcription enzyme mixture, and $0.5 \mu \mathrm{L}$ primer mixture, and nuclease-free water was added to a total volume of $10 \mu \mathrm{L}$. Reverse transcription was performed at $37^{\circ} \mathrm{C}$ for 15 min, followed by heat inactivation for $5 \mathrm{~min}$ at $98^{\circ} \mathrm{C}$ using an Applied Biosystems GeneAmp PCR System 9700 (Life Technologies, Darmstadt, Germany).

The RT-PCR mixture consisted of $0.25 \mu \mathrm{L}$ TaKaRa Ex Taq, $5 \mu \mathrm{L} 10 \times$ Ex Taq buffer, $4 \mu \mathrm{L}$ dNTP mixture, $0.5 \mu \mathrm{M}$ 
each of forward and reverse primers, $1 \mu \mathrm{L}$ template, and double distilled water to a total volume of $20 \mu \mathrm{L}$. The reaction procedure was as follows: initial denaturation at $98^{\circ} \mathrm{C}$ for $2 \mathrm{~min}$, followed by 50 cycles of denaturation at $98^{\circ} \mathrm{C}$ for $10 \mathrm{~s}$, annealing at $50^{\circ} \mathrm{C}$ for $30 \mathrm{~s}$, and extension at $72^{\circ} \mathrm{C}$ for 30 s. A final extension step was performed at $72^{\circ} \mathrm{C}$ for $7 \mathrm{~min}$. cDNA products were resolved on $2 \%(\mathrm{w} / \mathrm{v})$ agarose gels containing $0.025 \%(\mathrm{w} / \mathrm{v})$ ethidium bromide. The analysis was repeated thrice.

\section{Analysis of the Difference in LHCGR Expression}

The LHCGR mRNA levels in cultured granulosa cells of F1 follicles was analyzed using quantitative real-time PCR and the SYBR Premix Ex Taq II (Takara Bio., Shiga, Japan) on an Applied Biosystems StepOne real-time PCR system (Life Technologies) according to the method described previously (Guangmin et al., 2015). In brief, the PCR mixture $(20 \mu \mathrm{L})$ consisting of $10 \mu \mathrm{L}$ SYBR Premix Ex Taq II, 0.4 $\mu \mathrm{M}$ each of forward and reverse primers, $0.4 \mu \mathrm{L}$ ROX reference dye, $2 \mu \mathrm{L}$ template, and $6 \mu \mathrm{L}$ double distilled water were mixed in PCR tubes (Life Technologies). The thermal protocols for PCR were as follows: initial denaturation at $95^{\circ} \mathrm{C}$ for $30 \mathrm{~s}$ followed by 50 cycles of denaturation at $95^{\circ} \mathrm{C}$ for $5 \mathrm{~s}$, annealing and extension at $60^{\circ} \mathrm{C}$ for $34 \mathrm{~s}$, and a melting curve from 60 to $95^{\circ} \mathrm{C}$, increasing in increments of $0.5^{\circ} \mathrm{C}$ every $5 \mathrm{~s}$. Normalization was performed using the $G A P D H$ housekeeping gene as a control. Primer sequences are listed in Table 1. Real-time PCR data were analyzed using the $2^{-\Delta \Delta \mathrm{ct}}$ method.

\section{Measurement of Progesterone Levels}

Cell culture medium or blood sample was pre-cleared by centrifugation at $3,000 \times g$ for $20 \mathrm{~min}$ to remove cells and then stored at $-20^{\circ} \mathrm{C}$ until further use. For the progesterone assay, cell-free culture medium or serum was extracted in advance as described previously (Isobe et al., 2005). The culture medium or serum was mixed with $2 \mathrm{~mL}$ petroleum ether (Kanto Chemical Co., Tokyo, Japan) and shaken for 15 min. After decantation, the ether phase was evaporated in a glass tube. Borate buffer, consisting of $0.05 \mathrm{M}$ boric acid (Kanto Chemical Co.), $0.2 \%$ (w/v) bovine serum albumin (BSA) (Sigma-Aldrich) and $0.1 \mathrm{mg} / \mathrm{mL}$ thimerosal (Kanto Chemical Co.), was added into tubes for reconstitution, followed by an enzyme immunoassay with a rabbit anti- progesterone antibody (Isobe and Nakao, 2003). Cross reactivity of the anti-progesterone antibody with progesterone, $5 \alpha$-pregnanedione, 20 $\beta$-hydroxyprogesterone, deoxycorticosterone, pregnenolone, $5 \beta$-pregnane- $3 \alpha$-ol-20-one, and $17 \alpha$-hydroxyprogesterone were $100,5.8,0.7,0.62,0.2,0.1$, and $0.05 \%$, respectively. Horseradish peroxidase (SigmaAldrich) was conjugated with progesterone carboxymethyloxime (Sigma-Aldrich) using a mixed anhydride reaction. The sensitivity of the assay was $0.0055 \mathrm{ng} / \mathrm{mL}$. Intra- and inter-assay coefficients of variation were $9.6-10.9 \%$ and $10.8-16.6 \%$, respectively. Recovery rate ranged between $73 \%$ and $84 \%$. Samples from six quails were measured in duplicates.

\section{Statistical Analysis}

Continuous variables are expressed as the mean \pm standard deviation (SD) of at least three independent experiments. Statistical analyses were performed using one-way analysis of variance (ANOVA) followed by Duncan's multiple-range test with the Statview software (Abacus Concepts, Berkeley, CA, USA). Differences were considered statistically significant when the $P$ value was less than 0.05 .

\section{Results}

Fig. 1 shows the effect of melatonin, follicle size, and collection time post-oviposition on the secretion of progesterone by pre-ovulatory granulosa cells cultured for $12 \mathrm{~h}$. No statistical differences were observed between progesterone secretion by granulosa cells with or without melatonin administration $(P>0.05)$. When $\mathrm{F} 1$ follicle granulosa cells were cultured with 0.1 and $1 \mu \mathrm{g} / \mathrm{mL}$ melatonin, progesterone secretion by cells collected $3-6 \mathrm{~h}$ after oviposition was significantly less than that of cells collected $18-21 \mathrm{~h}$ after oviposition $(P<0.05)$; however, no differences between the two collection times were observed at other melatonin concentrations (Fig. 1a). Progesterone secretion by the granulosa cells of the F2 follicles was remarkably less for cells collected at 3-6h than by those collected at $18-21 \mathrm{~h}$ after oviposition when they were cultured with $0,0.0001$, and 1 $\mu \mathrm{g} / \mathrm{mL}$ melatonin $(P<0.05)$; however, this difference disappeared in the presence of other concentrations of melatonin (Fig. 1b). Progesterone secretion by F3 granulosa cells was significantly lower at 3-6h than for those collected $18-21 \mathrm{~h}$

Table 1. Primers used for PCR

\begin{tabular}{|c|c|c|c|}
\hline Gene & Primer sequence $\left(5^{\prime}-3^{\prime}\right)$ & Accession no. & Product size $(b p)$ \\
\hline \multirow[t]{2}{*}{ Mel-1a } & Forward: CAATGGATGGAATCTGGGA & NM_205362.1 & 333 \\
\hline & Reverse: GCTATGGGAAGTATGAAGTGG & & \\
\hline \multirow[t]{2}{*}{$M e l-1 b$} & Forward: TTTGCTGGGCACCTCTAAAC & NM_001293103.1 & 259 \\
\hline & Reverse: CGCTTGCTCTTCTGTCCATC & & \\
\hline \multirow[t]{2}{*}{ Mel-1c } & Forward: AGATAAGTGGGTTCCTGATGG & NM_205361.1 & 237 \\
\hline & Reverse: GCAAAGGTGCAAGAGTAAATC & & \\
\hline \multirow[t]{2}{*}{$L H C G R$} & Forward: TTGCACATTGAGGACGGAGC & NM_204936.1 & 194 \\
\hline & Reverse: GATTCGTTGCTCATGCCCTG & & \\
\hline \multirow[t]{2}{*}{$G A D P H$} & Forward: ATCACAGCCACACAGAAGACG & M11213 & 124 \\
\hline & Reverse: TGACTTTCCCCACAGCCTTA & & \\
\hline
\end{tabular}



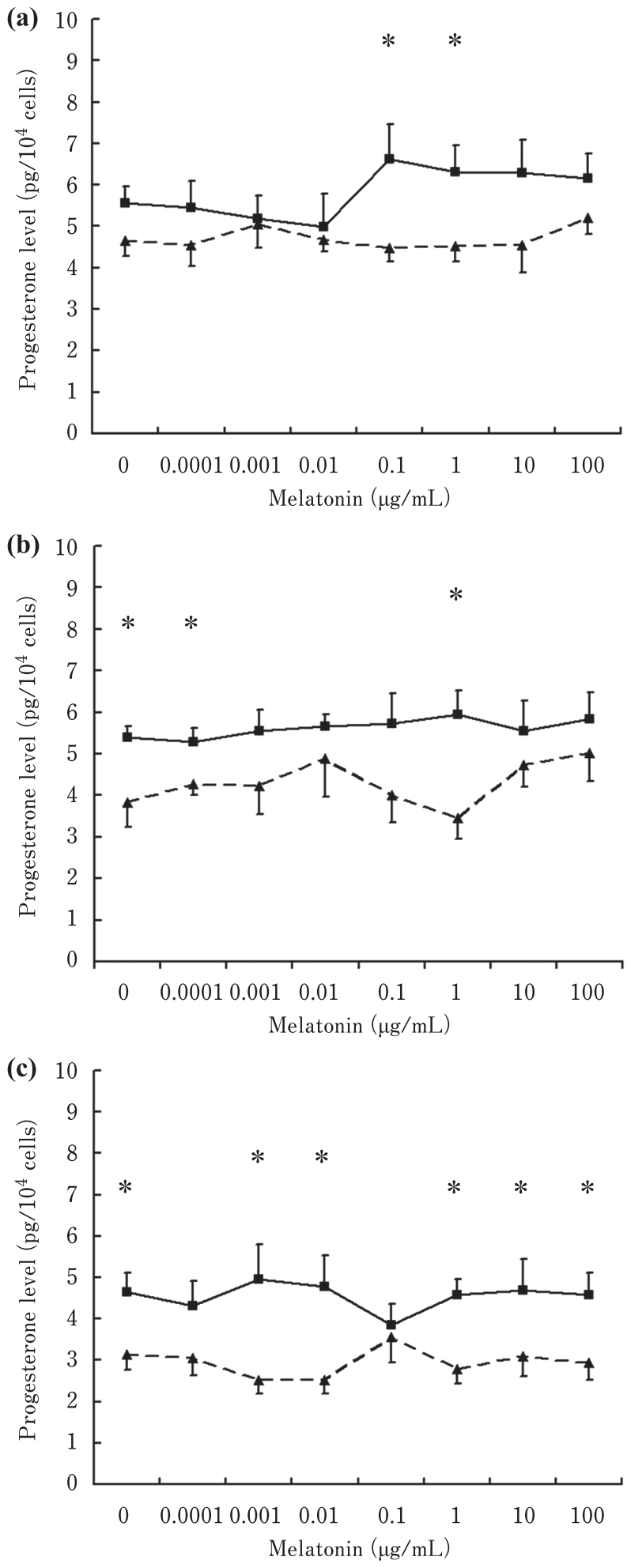

Fig. 1. Progesterone secretion by granulosa cells of Japanese quail cultured for $12 \mathrm{~h}$ with or without melatonin stimulation. Granulosa cells were obtained from (a) F1, (b) F2, or (c) F3 follicles, at 3-6h (triangles, dashed line) or 18-21 h (squares, solid line) after oviposition. Data are the mean $\pm \operatorname{SD}(n=6)$. *Values are significantly different between $3-6 \mathrm{~h}$ group and $18-21 \mathrm{~h}$ group $(P<0.05)$.

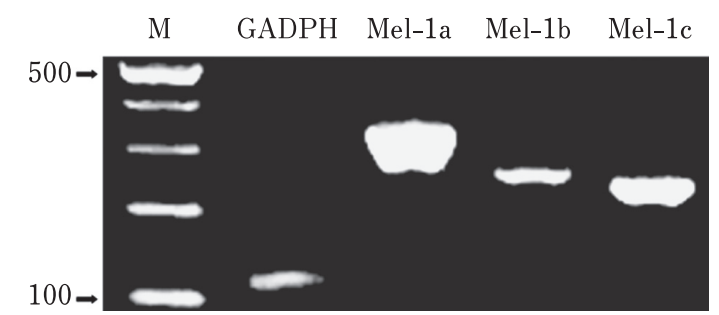

Fig. 2. The expression of melatonin receptor subtypes in cultured granulosa cells from F1 follicles of Japanese quail. The PCR products were electrophoresed on $2 \%$ agarose gel containing ethidium bromide $(n=3)$. M=marker.

after oviposition at nearly all melatonin concentrations, except 0.0001 and $0.1 \mu \mathrm{g} / \mathrm{mL}$ melatonin.

The expression profile of melatonin receptor subtypes in cultured granulosa cells of the F1 follicles showed that melatonin receptor subtypes (Mel-1a, 1b, and 1c) were expressed in granulosa cells of the Japanese quail (Fig. 2).

The effect of melatonin on the expression of LHCGR mRNA in cultured granulosa cells of the F1 follicles is shown in Fig. 3. Melatonin at two doses (0.0001 and 0.001 $\mu \mathrm{g} / \mathrm{mL}$ ) significantly suppressed LHCGR mRNA expression after culturing for $12 \mathrm{~h}(P<0.05)$ in cells collected at both 3-6 $\mathrm{h}$ and 18-21 $\mathrm{h}$ after oviposition.

With regard to the in vivo experiment, no statistical differences were observed between serum progesterone levels of quails at $6 \mathrm{~h}$ after oviposition with or without melatonin administration $(P>0.05)$. However, for animals injected with melatonin, the serum progesterone level was significantly less at $21 \mathrm{~h}$ after oviposition $(P<0.05)$ (Fig. 4).

\section{Discussion}

Progesterone plays a key role in regulating the reproductive activity ( $\mathrm{Yu}$ and Maeda, 2017). In birds, ovarian follicles maintain a monolayer of granulosa cells (Diez-Fraile et al., 2010). The pre-ovulatory follicles grow in size due to yolk incorporation and the granulosa cells produce progressively greater amounts of progesterone (Onagbesan et al., 2009; Sechman, 2013; Johnson, 2014). Granulosa cells can be collected from pre-ovulatory follicles of poultry bird and cultured in vitro, which provides a means for the study of progesterone biosynthesis in avian species. In the present study, we investigated the effect of melatonin on progesterone secretion by granulosa cells collected from F1-F3 preovulatory follicles at $3-6 \mathrm{~h}$ and $18-21 \mathrm{~h}$ after oviposition without LH stimulation in vitro. We demonstrated that melatonin does not affect the basal secretion of progesterone in cultured granulosa cells of the Japanese quail.

The pre-ovulatory progesterone surge is predominantly derived from the granulosa layer of the largest mature preovulatory follicle (F1) (Etches, 1994). The pre-ovulatory F1 follicle produces 30 times more progesterone than the F2 and $\mathrm{F} 3$ follicles in the absence of exogenous $\mathrm{LH}$ in vitro ( $\mathrm{Yu}$ et al., 1992) and granulosa cells of the F1 follicle are more 


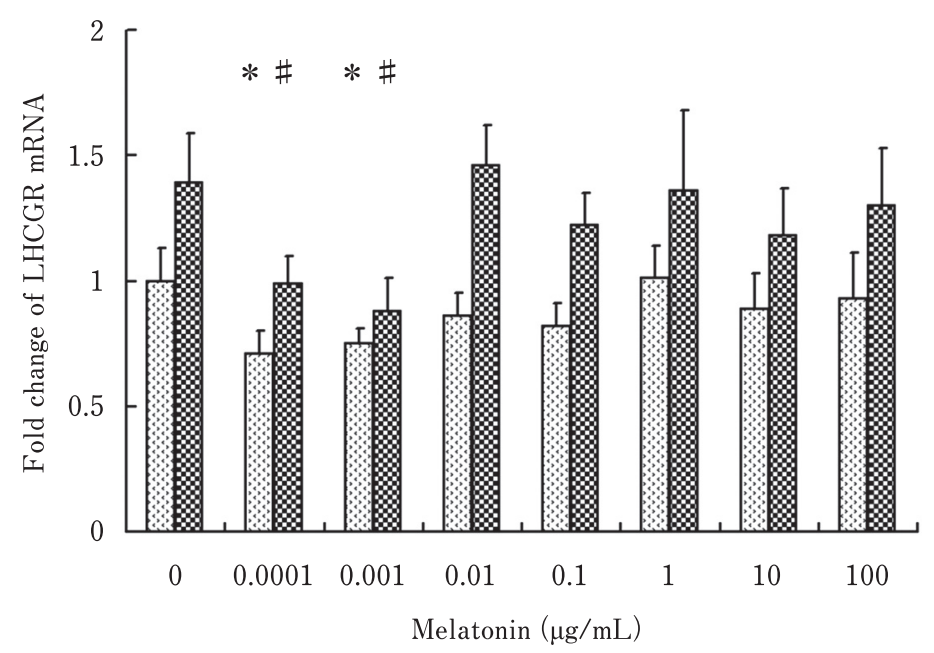

Fig. 3. The effect of melatonin on the expression of LHCGR mRNA in cultured granulosa cells from $F 1$ follicles of Japanese quail. Histograms filled with arrowheads present data of 3-6h, while filled with squares present data of $18-21 \mathrm{~h}$. Data are the mean $\pm \operatorname{SD}(n=6)$. *, ${ }^{*}$ Values are significantly different compared to the values of $0 \mu \mathrm{g} / \mathrm{mL}$ $(P<0.05)$.

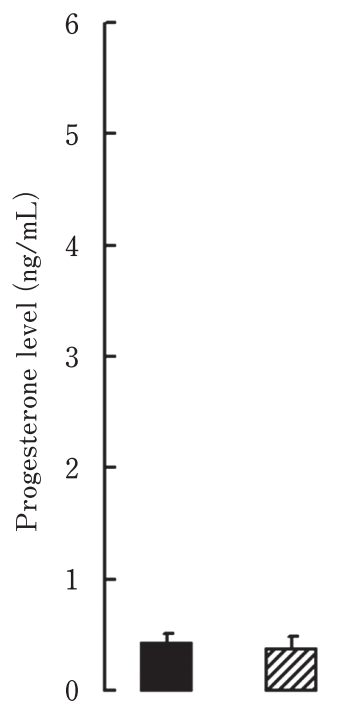

$6 \mathrm{~h}$ after oviposition

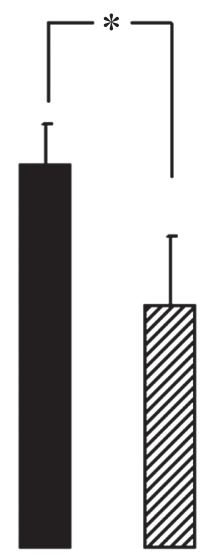

$21 \mathrm{~h}$ after oviposition

Fig. 4. Progesterone level in serum of Japanese quail with or without melatonin administration. Black histograms present data of the controls, while histograms filled with oblique lines present data of melatonin treatment. Data are the mean \pm SD $(n=6)$. *Values are significantly different at $P<0.05$.

responsive to $\mathrm{LH}$ stimulation than granulosa cells of the F3 follicle (Robinson et al., 1988). In addition, the pre-ovulatory release of LH is stimulated by the positive feedback action of progesterone in avian species (Johnson et al., 1985; Johnson

et al., 2002). Finally, adequate amounts of granulosa cells can be isolated from F1 follicles of the Japanese quail. Thus, we investigated the expression of melatonin receptor subtypes and the effect of melatonin on LHCGR mRNA in granulosa cells of the $\mathrm{F} 1$ follicles. We found that melatonin significantly suppressed LHCGR mRNA expression in the relatively lower concentrations used in our study. Moreover, decreased LHCGR expression suggests a concordant decrease in the responsiveness of melatonin-treated granulosa cells to LH.

To substantiate the above assumption, we investigated the effect of melatonin on progesterone production in vivo. There were no statistical differences between serum progesterone levels of Japanese quails at $6 \mathrm{~h}$ after oviposition with or without melatonin administration, which is similar to the basic conditions observed in vitro. The release of LH from the pituitary relates to the degree of maturation of the pre-ovulatory follicles (Etches, 1994). LH is not released from the pituitary when the $\mathrm{F} 1$ follicles are predicted to be immature (at 3-6 h after oviposition), maintaining $\mathrm{LH}$ at low basic levels in circulating blood (Hrabia et al., 2014). At 18-21 $\mathrm{h}$ after oviposition, the F1 follicles are predicted to mature, and the pituitary starts releasing LH into circulating blood (Reece, 2004). The progesterone level in blood reaches a peak with a surge in LH levels (NakagawaMizuyachi et al., 2010). In the present study, at $21 \mathrm{~h}$ after oviposition, the serous progesterone level was significantly lower in quails injected with melatonin, which is in agreement with an earlier in vitro study performed by Murayama et al. (1997). In their study, the dose-response curve for LHstimulated progesterone production of hen granulosa cells shifted to a higher concentration of LH to attain ED50 in the 
presence of melatonin. Therefore, these effects of melatonin on progesterone production are consistent with the decreased LHCGR mRNA expression demonstrated by our study. The findings in the present study and published information can explain, at least in part, the phenomenon of longer nocturnal hours being de-stimulatory in poultry bird reproductive cycle. Prolonged nocturnal hours stimulate melatonin biosynthesis in the pineal gland, which subsequently increases melatonin release in the bloodstream. The elevated concentration of melatonin in circulating blood inhibits LHCGR mRNA expression in the ovarian granulosa cells, which thereby reduces the LH responsiveness of granulosa cells in the pre-ovulatory follicles. With the decrease in LHstimulated progesterone production by granulosa cells, the serum progesterone level decreases, which weakens the positive feedback action of progesterone on the preovulatory release of LH. Thus, decreased serum LH levels ulteriorly reduce progesterone production by granulosa cells. These findings can also explain why short-day photoperiod or administration of melatonin decreases the ovary weight of developing avian species (Darre, 2011). Accumulating evidence may account for the fact that poultry birds produce well on long days and short nights.

In summary, we found that melatonin receptor subtypes (Mel-1a, 1b, and 1c) were expressed in granulosa cells of F1 follicles of the Japanese quail. Melatonin does not affect the basal secretion of progesterone in cultured granulosa cells of the F1-F3 follicles but suppresses LHCGR mRNA expression in the granulosa cells of the F1 follicles. In addition, melatonin treatment has no influence on the serum progesterone concentration at $6 \mathrm{~h}$ post oviposition; however, it suppresses progesterone level at $21 \mathrm{~h}$ post oviposition in the Japanese quail.

\section{References}

Abd-Allah AR, El-Sayed el SM, Abdel-Wahab MH and Hamada FM. Effect of melatonin on estrogen and progesterone receptors in relation to uterine contraction in rats. Pharmacological Research, 47: 349-354. 2003.

Abecia JA, Forcada $\mathrm{F}$ and Zúniga $\mathrm{O}$. The effect of melatonin on the secretion of progesterone in sheep and on the development of ovine embryos in vitro. Veterinary Research Communications, 26: 151-158. 2002.

Chuffa LG, Seiva FR, Fávaro WJ, Amorim JP, Teixeira GR, Mendes LO, Fioruci-Fontanelli BA, Pinheiro PF, Martinez M and Martinez FE. Melatonin and ethanol intake exert opposite effects on circulating estradiol and progesterone and differentially regulate sex steroid receptors in the ovaries, oviducts, and uteri of adult rats. Reproductive Toxicology, 39: 40-49. 2013.

Darre MJ. University of Connecticut Web. http://web.uconn.edu/ poultry/poultrypages. Accessed on May 24, 2011.

Davis FC. Melatonin: Role in development. Journal of Biological Rhythms, 12: 498-508. 1997.

Diez-Fraile A, Mussche S, Vanden Berghe T, Espeel M, Vandenabeele P and D'Herde KG. Expression of calciumsensing receptor in quail granulosa explants: a key to survival during folliculogenesis. Anatomical Record (Hoboken), 293: 890-899. 2010.

Etches RJ. Maturation of ovarian follicles. In: Reproductive Biology of Poultry (Cunningham FJ, Lake PE and Hewitt D eds.). pp. 29-49. Cambridge Press. Cambridge. 1994.

Fernández-Gil B, Moneim AEA, Ortiz F, Shen YQ, Soto-Mercado V, Mendivil-Perez M, Guerra-Librero A, Acuña-Castroviejo D, Molina-Navarro MM, García-Verdugo JM, Sayed RKA, Florido J, Luna JD, López LC and Escames G. Melatonin protects rats from radiotherapy-induced small intestine toxicity. PLOS ONE, 12: e0174474. 2017.

Galano A, Tan DX and Reiter RJ. On the free radical scavenging activities of melatonin's metabolites, AFMK and AMK. Journal of Pineal Research, 54: 245-257. 2013.

Galano A, Tan DX and Reiter RJ. Cyclic 3-hydroxymelatonin, a key metabolite enhancing the peroxyl radical scavenging activity of melatonin. RSC Advances, 4: 5220-5227. 2014.

Guangmin Y, Haq IU, Khan SH and Zeng M. Actin filaments are necessary for FSH-induced CYP19A1 transcription in bovine granulosa cells in vitro. Pakistan Veterinary Journal, 35: 5357. 2015.

Hardeland R, Cardinali DP, Brown GM and Pandi-Perumal SR. Melatonin and brain inflammaging. Progress in Neurobiology, 127-128: 46-63. 2015.

Hrabia A, Sechman A and Rzasa J. Effect of growth hormone on basal and LH-stimulated steroid secretion by chicken yellow ovarian follicles. An in vitro study. Folia Biologica (Kraków), 62: 313-319. 2014.

Ito T, Yoshizaki N, Tokumoto T, Ono H, Yoshimura T, Tsukada A, Kansaku N and Sasanami T. Progesterone is a sperm-releasing factor from the sperm-storage tubules in birds. Endocrinology, 152: 3952-3962. 2011.

Isobe $\mathrm{N}$ and Nakao T. Direct enzyme immunoassay of progesterone in bovine plasma. Animal Science Journal, 74: 369-373. 2003.

Isobe N, Nakao T, Yamashiro H and Shimada M. Enzyme immunoassay of progesterone in the feces from beef cattle to monitor the ovarian cycle. Animal Reproduction Science, 87: 1-10. 2005.

Johnson AL. The avian ovary and follicle development: some comparative and practical insights. Turkish Journal of Veterinary and Animal Sciences, 38: 660-669. 2014.

Johnson PA, Johnson AL and van Tienhoven A. Evidence for a positive feedback interaction between progesterone and luteinizing hormone in the induction of ovulation in the hen, Gallus domesticus. General and Comparative Endocrinology, 58: 478-485. 1985.

Johnson AL, Solovieva EV and Bridgham JT. Relationship between steroidogenic acute regulatory protein expression and progesterone production in hen granulosa cells during follicle development. Biology of Reproduction, 67: 1313-1320. 2002.

McDerment NA, Wilson PW, Waddington D, Dunn IC and Hocking PM. Identification of novel candidate genes for follicle selection in the broiler breeder ovary. BMC Genomics, 13: 494. 2012.

Mehaisen GMK, Saeed AM, Gad A, Abass AO, Arafa M and ElSayed A. Antioxidant capacity of melatonin on preimplantation development of fresh and vitrified rabbit embryos: morphological and molecular aspects. PLOS ONE, 10: e0139814. 2015.

Moreira AJ, Ordoñez R, Cerski CT, Picada JN, García-Palomo A, Marroni NP, Mauriz JL and González-Gallego J. Melatonin activates endoplasmic reticulum stress and apoptosis in rats with diethylnitrosamine-induced hepatocarcinogenesis. PLOS ONE, 10: e0144517. 2015.

Murayama T, Kawashima M, Takahashi T, Yasuoka T, Kuwayama $\mathrm{T}$ and Tanaka K. Direct action of melatonin on hen ovarian 
granulosa cells to lower responsiveness to luteinizing hormone. Proceedings of the Society for Experimental Biology and Medicine, 215: 386-392. 1997.

Nakagawa-Mizuyachi K, Takahashi T, Kasai S, Nakayama H and Kawashima M. Calcitonin directly inhibits luteinizing hormonestimulated progesterone production in granulosa cells of the largest follicle of hen. Journal of Poultry Science, 47: 170175. 2010.

Onagbesan O, Bruggeman V and Decuypere E. Intra-ovarian growth factors regulating ovarian function in avian species: a review. Animal Reproduction Science, 111: 121-140. 2009.

Pang SF, Li L, Ayre EA, Pang CS, Lee PP, Xu RK, Chow PH, Yu $\mathrm{ZH}$ and Shiu SY. Neuroendocrinology of melatonin in reproduction: Recent developments. Journal of Chemical Neuroanatomy, 14: 157-166. 1998.

Rangel PL, Rodríguez A, Rojas S, Sharp PJ and Gutierrez CG. Testosterone stimulates progesterone production and STAR, P450 cholesterol side-chain cleavage and LH receptor mRNAs expression in hen (Gallus domesticus) granulosa cells. Reproduction, 138: 961-969. 2009.

Reece WO. Dukes' Physiology of Domestic Animals. 12th ed. Cornell University Press. Ithaca-London. 2004.

Robinson FE, Etches RJ, Anderson-Langmuir CE, Burke WH, Cunningham FJ, Ishii S, Sharp PJ and Talbot RT. Steroidogenic relationship of gonadotrophin hormones in the ovary of the hen (Gallus domesticus). General and Comparative Endocrinology, 69: 455-466. 1988.

Sechman A. The role of thyroid hormones in regulation of chicken ovarian steroidogenesis. General and Comparative Endocrinology, 190: 68-75. 2013.

Söderquist F, Janson ET, Rasmusson AJ, Ali A, Stridsberg M and Cunningham JL. Melatonin immunoreactivity in malignant small intestinal neuroendocrine tumours. PLOS ONE, 11: e0164354. 2016.

Taketani T, Tamura H, Takasaki A, Lee L, Kizuka F, Tamura I, Taniguchi K, Maekawa R, Asada H, Shimamura K, Reiter RJ and Sugino N. Protective role of melatonin in progesterone production by human luteal cells. Journal of Pineal Research,
51: 207-213. 2011.

Tyagi E, Agrawal R, Nath C and Shukla R. Effect of melatonin on neuroinflammation and acetylcholinesterase activity induced by LPS in rat brain. European Journal of Pharmacology 640: 206-210. 2010.

Vanecek J. Cellular mechanisms of melatonin action. Physiological Reviews, 78: 687-721. 1998.

Wang F, Tian XZ, Zhou YH, Tan DX, Zhu SE, Dai YP and Liu GS. Melatonin Improves the quality of in vitro produced (IVP) bovine embryos: implications for blastocyst development, cryotolerance, and modifications of relevant gene expression. PLOS ONE, 9: e93641. 2014.

Wang SJ, Liu WJ, Wu CJ, Ma FH, Ahmad S, Liu BR, Han L, Jiang XP, Zhang SJ and Yang LG. Melatonin suppresses apoptosis and stimulates progesterone production by bovine granulosa cells via its receptors (MT1 and MT2). Theriogenology, 78: 1517-1526. 2012.

Webley GE and Hearn JP. Local production of progesterone by the corpus luteum of the marmoset monkey in response to perfusion with chorionic gonadotrophin and melatonin in vivo. Journal of Endocrinology, 112: 449-457. 1987.

Webley GE and Luck MR. Melatonin directly stimulates the secretion of progesterone by human and bovine granulosa cells in vitro. Journal of Reproduction and Fertility, 78: 711-717. 1986.

$\mathrm{Yu}$ GM and Maeda T. Inline progesterone monitoring in the dairy industry. Trends in Biotechnology, 35: 579-582. 2017.

$\mathrm{Yu}$ MW, Robinson FE and Etches RJ. Quantification of ovarian steroidogenesis in the domestic-fowl by incubation of intact large follicles. Poultry Science, 71: 346-351. 1992.

Zhang N, Sun Q, Zhang H, Cao Y, Weeda S, Ren S and Guo YD. Roles of melatonin in abiotic stress resistance in plants. Journal of Experimental Botany, 66: 647-656. 2015.

Zhou W, Zhang X, Zhu CL, He ZY, Liang JP and Song ZC. Melatonin receptor agonists as the "perioceutics" agents for periodontal disease through modulation of porphyromonas gingivalis virulence and inflammatory response. PLOS ONE, 11: e0166442. 2016. 